\title{
Control of Diesel-electric AC/DC Traction Drive of Motor Truck WŽB 10.1-M
}

\author{
Zdeněk Mašek ${ }^{1)}$, Jaroslav Novák ${ }^{2)}$, Ondřej Sadílek ${ }^{3)}$ and Tomáš Lelek ${ }^{4)}$ \\ 1) 2) 3) 4) University of Pardubice, Faculty of Transport Engineering, Department of Electrical and Electronic Engineering \\ and Signalling in Transport (KEEZ), Czech Republic, \\ e-mail: ${ }^{1)}$ zdenek.masek@upce.cz, ${ }^{2)}$ jaroslav.novak@upce.cz, ${ }^{3)}$ ondrej.sadilek@upce.cz, ${ }^{4)}$ tomas.lelek@upce.cz
}

\begin{abstract}
The paper describes the control of traction drive and control systems properties of a special rail vehicle WŽB10.1-M used in the Prague metro (subway). Measured values of main quantities of the control system and experience from duty are included. Software for the traction drive control system was developed at the University of Pardubice.
\end{abstract}

Keywords - rail, vehicle, metro, subway, traction, drive, diesel, engine, control, system, tractive, effort, WŽB, MUV, $M M D$

\section{INTRODUCTION}

The motor truck WŽB 10.1-M is used in the Prague metro for railway line maintenance. The WŽB 10.1-M motor truck is made by CZ Loko a.s. The WŽB 10.1-M is a reconstructed old polish vehicle WŽB 10-M which was made by Kolzam in the 80 's and 90 's of the $20^{\text {th }}$ century. Team of the Electrical and Electronic Engineering and Signalling in Transport Department of the University of Pardubice developed control algorithms and created software for traction drive control of the said vehicle. Earlier the same team developed software for traction drive control of special rail vehicles MUV 74.1, MUV 74.1-M, MUV 74.2, MMD, M27 equipped with hydrostatic transmission ([1], [2], [3], [4]). The WŽB $10.1-\mathrm{M}$ is a two axle vehicle equipped with diesel-electric AC/DC traction drive. Maximum speed is $50 \mathrm{~km} / \mathrm{h}$ while maximum speed used in metro is $40 \mathrm{~km} / \mathrm{h}$. Vehicle weight is 13.9 tons, maximum load 7 tons. More vehicle parameters are shown in Table I.

TABLE I.

VEHICLE PARAMETERS

\begin{tabular}{|l|l|}
\hline Track gauge & $1435 \mathrm{~mm}$ \\
\hline Wheelset arrangement & Bo Bo \\
\hline Max. operating speed & $50 \mathrm{~km} / \mathrm{h}$ \\
\hline Max. speed of traction motors & $47001 / \mathrm{min}$ \\
\hline Power transmission & electric AC/DC \\
\hline Nominal towing capacity & $19.2 \mathrm{kN}$ \\
\hline Max. towing capacity & $36.5 \mathrm{kN}$ \\
\hline Nominal current of traction motor & $180 \mathrm{~A}$ \\
\hline Max. current of traction motor & $300 \mathrm{~A}$ \\
\hline Number of excitation shunting levels & 1 level, 55 \% \\
\hline Max. DC voltage (after rectifier) & $900 \mathrm{~V}$ \\
\hline Diesel engine & $\mathrm{CAT} \mathrm{C4.4}(129,5 \mathrm{~kW})$ \\
\hline Diesel engine speed range & $800-22001 / \mathrm{min}$ \\
\hline Weight empty / with load & $13900 / 20900 \mathrm{~kg}$ \\
\hline
\end{tabular}

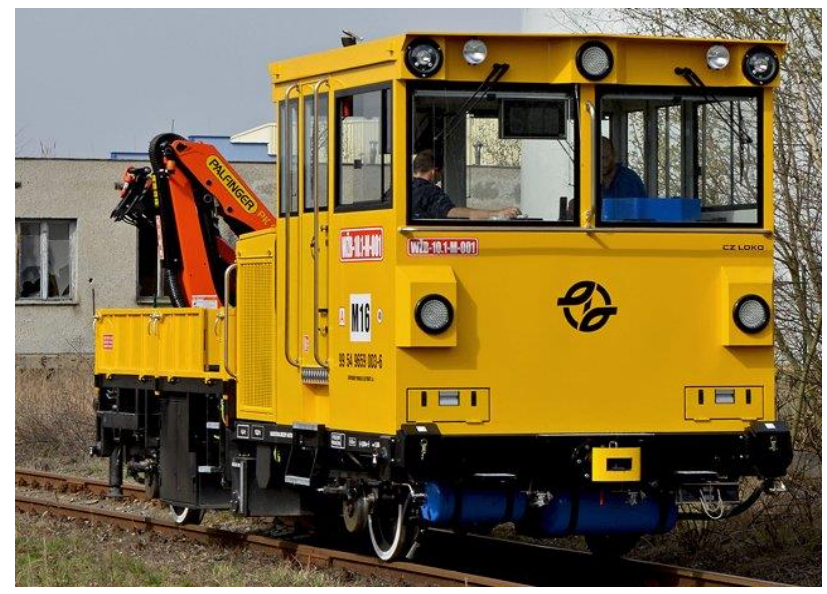

Fig. 1. Motor truck WŽB 10.1-M (source: http://spz.logout.cz/).

\section{TRACTION DRIVE STRUCTURE}

The structure of the traction drive of the WŽB 10.1-M motor truck is in Fig. 2. Primary source of power is the Caterpillar C4.4 $129 \mathrm{~kW}$ diesel engine connected to the Leroy Sommer LSA46.2 synchronnous generator with a rotary exciter inside. The rotary exciter is controlled from a static exciter $(0-5 \mathrm{~A})$, that is controlled from a control system (0 - $20 \mathrm{~mA})$.

Two series DC motors (SKD TE023 $67 \mathrm{~kW}$ ) are electrically connected in series. They are equipped with one field-weakening level (55\% of the nominal value). Traction motors are self air cooled. Self cooling significantly limits the time spent on a high current while vehicle speed is low. The shunt resistor (RS1) is switched by contator (KM41). The shunt contactor current capacity is $180 \mathrm{~A}$. The shunt is applied at approx. $32 \mathrm{~km} / \mathrm{h}$. Current flowing to the traction motors is fed over the main contactor (KM11) that electrically disconnects the traction motors from the voltage source. The main contactor is controlled from the control system. The change of driving direction is done by change of the current flow in exitation winding of the traction motors. The mechanical rotation element (QP) is used for this purpose. It is controlled by two electro-pneumatical valves switched from the control system. The traction DC voltage $(0-1000 \mathrm{~V})$ and current $(0-400 \mathrm{~A})$ are measured by isloated transducers with current output $(0-20 \mathrm{~mA})$. 


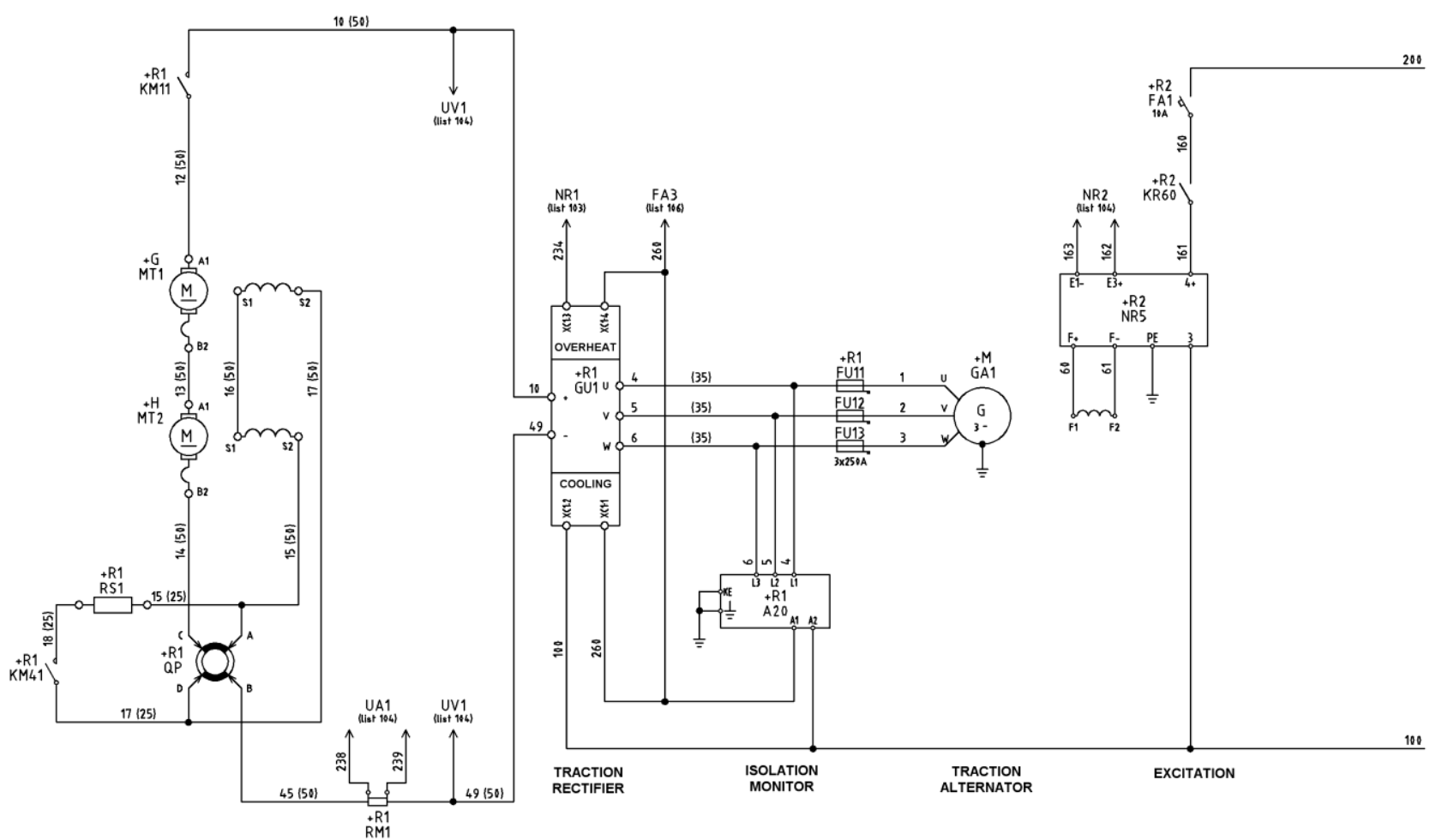

Fig. 2. Traction drive electrical circuit [8].

\section{TRACTION DRIVE CONTROL}

The traction drive control software ensures following tasks:

- Tractive effort control.

- Field weakening of the DC motors.

- Calculation of desired speed for the diesel engine.

- Temperature protection of the traction motors.

- Vehicle velocity control in constant velocity mode.

- Anti-slip protection.

- On board diagnostic of the inputs and outpus of thecontrol system, diagnostic interface for service men.

The tractive effort control is realized by the following SW block:

- Traction current controller.

- Traction power controller.

- Traction voltage controller (limiter).

Division to the three SW blocks is based on the load characteristic of the traction generator (more accurately, the $\mathrm{DC}$ voltage $\mathrm{U}_{\mathrm{G}}$ as a function of DC current $\mathrm{I}_{\mathrm{G}}$ after rectifier). Characteristic is divided into the three parts: constant current, constant power, constant voltage (Fig. 3).

The shape of the traction generator load characteristic shown in Fig. 3 is influenced by:
- maximum DC current as a function of the diesel engine speed so that the traction generator does not overheat,

- maximum excitation current of the traction generator,

- $\quad$ engine speed optimalization in order to achieve minimum fuel consumption.

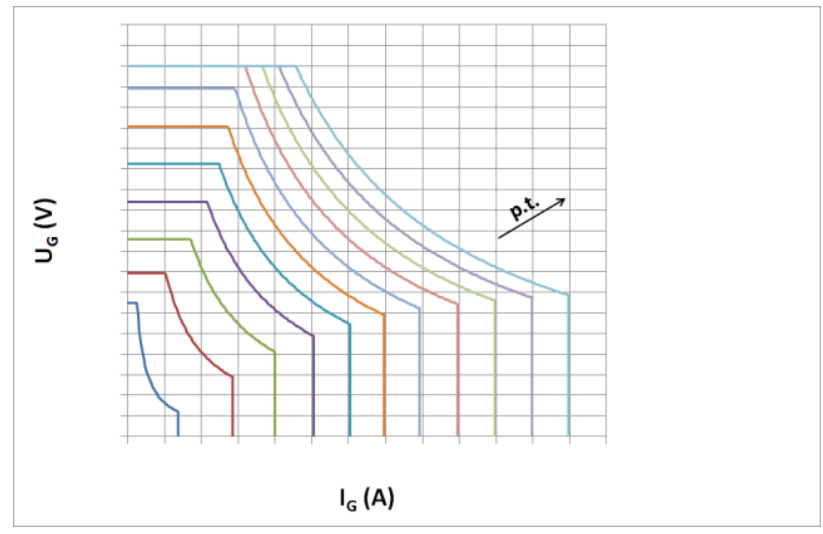

Fig. 3. Load curve of the traction generator.

The load characteristic of the diesel engine, i.e. the desired engine speed according to the desired percent of the tractive effort, depends on the load characteristic of the generator and vice versa. The generator inertia and power consumption of auxiliary devices has to be accounted for in the load characteristic of the diesel engine. 


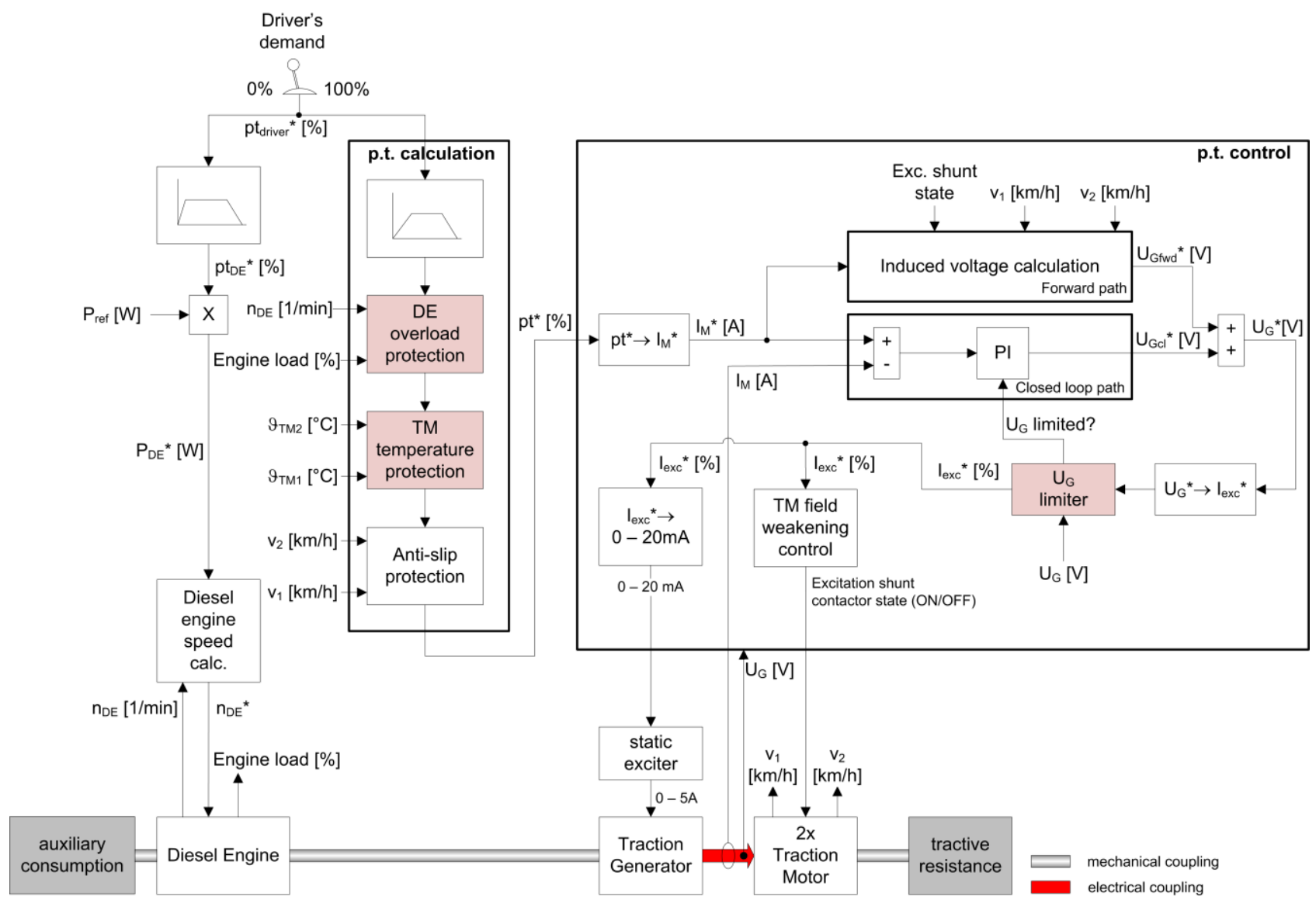

Fig. 4. Control structure.

There are number of ways how to control the AC/DC diesel-electric drive. The baseline of our control structure is based on designs described in [9], [11]. The temperature protection and anti-slip control were added.

The simplified structure of the used traction drive control is shown in Fig. 4.

Driver sets the desired tractive effort $(0-100 \%)$ and desired combustion engine speed. Both demands are ramped. Demand $100 \%$ presents the nominal tractive effort curve $\left(F_{\text {wheel }}=f(v)\right)$. The control software includes two layers. The higher layer calculates the final desired tractive effort in percent. The lower layer converts desired percent of the tractive effort to the desired motor current. It also controls shunting and calculates excitation current of the traction generator. This architecture separates quantities independent on hardware (percent of tractive effort) from quantities dependent on hardware (current, voltage). Software is then more robust to changes, adding of new properties is easier. All higher level functions like the diesel engine overload protection, traction motors temperature protection, anti-slip protection act on percent of the tractive effort. The desired current is calculated in the lower layer afterwards.

\section{A. Calculation of desired percent of tractive effort}

This block ensures calculation of final tractive effort ni percent (abbreviation p.t. will be used in the text from now). Calculated p.t. inputs to the p.t. controller.
The desired p.t. from driver can be reduced by blocks in the calculation path.

\section{1) Diesel engine overload protection block}

The DE overload protection block reduces p.t. if necessary so that the engine would not be overloaded. The engine overload protection reacts on engine speed drop and/or load value that engine sends via J1939 CAN bus to the control system. The diesel engine overload protection is implemented as the PID controller.

\section{2) Traction motors temperature protection block}

The TM temperature protection block reduces p.t. if necessary so that the temperature of the traction motors would be kept under a maximum allowable level. Isolation class of the traction motor SKD TE023 is N/F $\left(210{ }^{\circ} \mathrm{C} /\right.$ $155^{\circ} \mathrm{C}$ ). The motor is self-cooled. Temperature of each motor is measured by Pt100 sensor placed inside of the stator interpoles. Temperatures of interpoles and commutator are the most important because they are getting warm the fastest of all parts of motor. The temperature measured by Pt100 during transients (e.g. motor is warming up) differs from the real temperature. For example during the warm-up phase the measured temperature is lower than the real temperature by more than $50 \%$. In addition the temperature difference depends on the motor current and speed. The higher the current, the higher the temperature difference (real motor temperature is higher than the measured one). This makes the motor temperature protection more difficult. The used 
solution is simple but not very efficient. No motor thermal model is used. At first the real motor temperature is calculated from the temperature measured by Pt100. Next the p.t. is limited or reduced by the PI controller if temperature is too high. The motor manufacturer measured several thermal characteristics for different currents and motor speeds [5]. Thermal characteristics for current $189 \mathrm{~A}$ and motor speed $941 / \mathrm{min}(1 \mathrm{~km} / \mathrm{h})$ were then used in software for calculation of the real motor temperature from the measured temperature by Pt100. This curve was selected because the working point matches the worst case in a real world - towing mass 25 tons, $40 \%$ grade, $1 \mathrm{~km} / \mathrm{h}$. Under these conditions the motor temperature reaches the maximum value after approx. 23 minutes. The used solution has a drawback. If the motor current is lower than $189 \mathrm{~A}$, the calculated motor temperature would be higher than the real one and protection begins to limit the p.t. even though the real motor temperature is still under the maximum permissible value. It was mentioned earlier that the vehicle can run only approx. 23 minutes in the worst case load and velocity scenario. It was found unacceptable (too short time) during the field tests. Therefore vehicle's manufacturer decided to mount an additional cooling fan on each traction motor. The auxiliary electric cooling fans $(24 \mathrm{~V} / 600 \mathrm{~W})$ will cool down the motors enough to run vehicle for unlimited time in the worst case of load and velocity scenario. The fans are controlled from the control system with two states ON/OFF logic according to the selected mode (normal or closed loop velocity control), measured motor temperature, measured $24 \mathrm{~V}$ battery voltage, diesel engine state (stopped or running). In case of a Pt100 failure in both motors, the p.t. is greatly reduced to prevent the motors from overheating.

\section{3) Anti-slip protection block}

The anti-slip protection protects wheels from slipping. The anti-slip protection doesn't act on brakes, it only reduces desired p.t. if necessary. Slip is detected from comparison of the axle speeds and/or from acceleration. If slip is detected, p.t. begins to continuously decrease.

The wheel slip in percent is defined as follows:

$$
\text { wheel } \operatorname{sip}(\%)=100 \cdot \frac{\mathrm{abs}\left(v_{1}-v_{2}\right)}{\min \left(v_{1}, v_{2}\right)+e p s}
$$

where $v_{1}$ and $v_{2}$ are the axle speeds, eps is machine precision in order to prevent division by zero if the speed is zero.

Decreasing of p.t. stops when slip disappears or p.t. reaches $0 \%$. Then the p.t. ramps up back to desired value (Fig. 5). The used algorithm is the base of more sophisticated algorithms like [14].

The process repeats if slip occurs again. The ramp slopes were tuned experimentally on the test track. The anti-slip protection function is satisfactory in the context of available time to development, available developers and cost.

\section{B. Desired motor current calculation}

The main idea is to control the power output from the diesel engine, i.e. to control the power input to the traction generator. The p.t. controller calculates the excitation current for the traction generator according to the desired
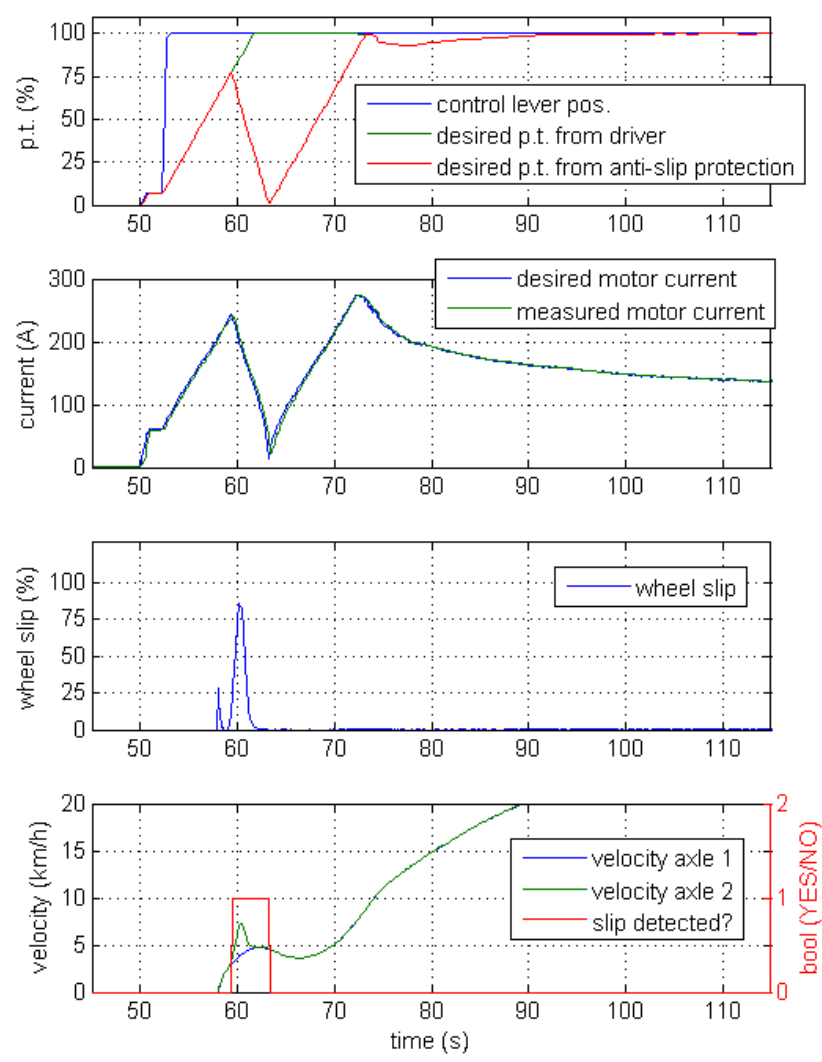

Fig. 5. Anti-slip protection.

p.t. and selects field-weakening level of the traction motors (full or $55 \%$ excitation). The generator excitation current is calculated from the diesel engine speed and desired current to the traction motors. The desired traction motor current is calculated from the generator load curve (Fig. 3). There are three regions on each load curve for particular p.t.:

- $\quad$ constant current, $I_{G}=$ const.,

- constant power,

- constant voltage, $U_{G}=$ const.

The block $p t^{*} \rightarrow I_{M}{ }^{*}$ calculates motor current in the constant current and constant power region. The block $U_{G}$ limiter ensures calculation of the generator excitation current in the constant voltage region independently on calculation of the desired motor current $I_{M}{ }^{*}$.

$I_{G}$ current is the current flowing from rectifier, $I_{M}$ is the current flowing through the each motor, $I_{M}=I_{G}$.

The desired motor current $I_{M}{ }^{*}$ in each region is calculated and the minimum value is selected afterwards. This ensures smooth transition between the constant current and constant power regions. This algorithm was successfully used on the previous MUV 74.x vehicles equipped with a hydrostatic transmission. Algorithms are the same, only the pressure and flow were replaced by the current and voltage.

In the constant current region $I_{M}=I_{G}=$ const. (constant tractive effort in $\mathrm{kN}$ ) the desired motor current is read from the armature current - torque curve at full excitation (Fig. 6). The curve was supplied by the motor manufacturer. 


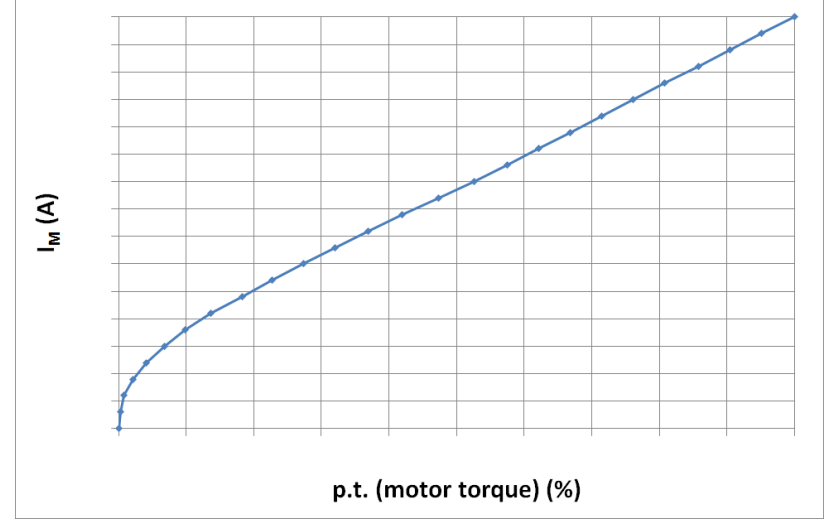

Fig. 6. Traction motor armature current - torque curve.

The desired p.t. equals to motor torque (Eq. (1)).

$$
I_{M_{-} F=c \text { const. }}^{*}(A)=f\left(M_{M}(N m)\right)=f(\text { p.t. }(\%))
$$

In the constant power region the desired motor current is calculated from the desired p.t. (p.t. means desired power in this case), measured traction voltage and generator efficiency. The generator efficiency is used in calculation because we control constant input power to the generator (i.e. constant power output from the diesel engine to the generator), not the output power from generator.

The generator efficiency is not constant, it depends on the delivered current and voltage. Field tests prove almost constant efficiency at full p.t. and vehicle velocities. Therefore one constant efficiency is used in calculation. The different efficiency at small p.t. is not an issue, the diesel engine load curve is designed with high enough reserve of the available engine power to accept variation in the generator efficiency at different operating points (Eq. (2)).

$$
I_{M_{-} P_{- \text {const. }}}^{*}(A)=\frac{P_{R E F}(W) \cdot \frac{\eta_{G}(\%)}{100} \cdot \frac{p t^{*}(\%)}{100}}{U_{M}(V)}
$$

Where:

$P_{R E F}$ - generator input power reference $(100 \mathrm{~kW})$

$\eta_{G}$ - traction generator efficiency (percent)

$U_{M}$ - measured voltage at rectifier output

$p t$ - desired tractive effort (percent)

\section{Motor current controller}

The calculated desired motor current inputs into the current controller. The desired traction voltage (voltage on the rectifier output) outputs from the current controller. The current controller contains two paths - forward path and closed loop path.

\section{1) Forward path}

The forward path compensates for induced voltage of the traction motors. The induced voltage is calculated from curves supplied by the motor manufacturer [5]. In the field weakening case the calculated induced voltage is lowered according to the excitation level.

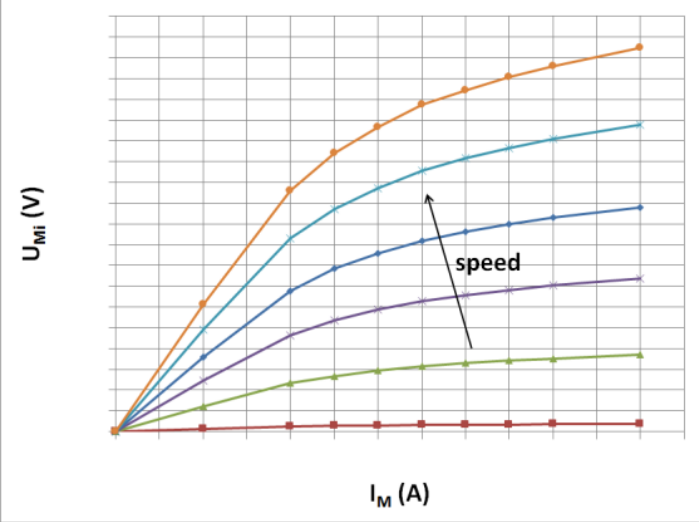

Fig. 7. Induced voltage of the traction motor for full excitation.

\section{2) Closed loop path}

The PI controller is used for the motor current control. The controller compensates for Joule losses of the traction motors and generator and inaccuracies in the forward path. Controller constants are set experimentally so that the current tracks desired value well and without overshoots. A good current tracking prevents the diesel engine from overloading during the transients. The time constant of the controlled plant is approx. 500 milliseconds.

The final desired voltage $U_{G}{ }^{*}$ is the sum of the desired voltages from the forward and closed loop paths. The block $U_{G}{ }^{*} \rightarrow I_{e x c}{ }^{*}$ converts the desired voltage to excitation current of the generator $\left(I_{e x c}{ }^{*}\right)$. The block $U_{G}$ limiter reduces the desired generator excitation current if the measured voltage $U_{G}$ is higher than the maximum acceptable voltage at the desired p.t. (constant voltage part of load characteristic of generator (Fig. 3). The voltage limiter has to work well at all operating points (different loads and speeds). It is implemented as the closed loop controller. If limitation occurs a logical signal is fed back to the PI controller to prevent winding up. The PI controller stops integration.

Main quantities of traction drive are shown in Figs. 8 and 9. Drive behaviour while the p.t. changes is shown in Fig. 8. Acceleration at the $100 \%$ tractive effort is shown in Fig. 9. At $32 \mathrm{~km} / \mathrm{h}$ the shunt resistor is switched on, at $20 \mathrm{~km} / \mathrm{h}$ the shunt resistor is switched off. Transition is smooth with almost no engine load deviation and no jerk. The difference between the desired and measured voltages $U_{G}$ in Fig. 9 is caused by the implementation of the block $U_{G}{ }^{*} \rightarrow I_{e x c}{ }^{*}$. This block converts the desired $U_{G}{ }^{*}$ to the desired generator excitation current $I_{e x c}{ }^{*}$. In fact, the desired $U_{G}{ }^{*}$ quantity from the motor current controller is more likely the desired generator excitation current rather than generator voltage. The used method of conversion causes the difference between the desired and measured $U_{G}$ but it is no issue. It is only the question of calibration. The closed-loop part of motor current controller compensates for inaccuracies as it can be seen in Fig. 3 (the green curve called "closed loop path"). 

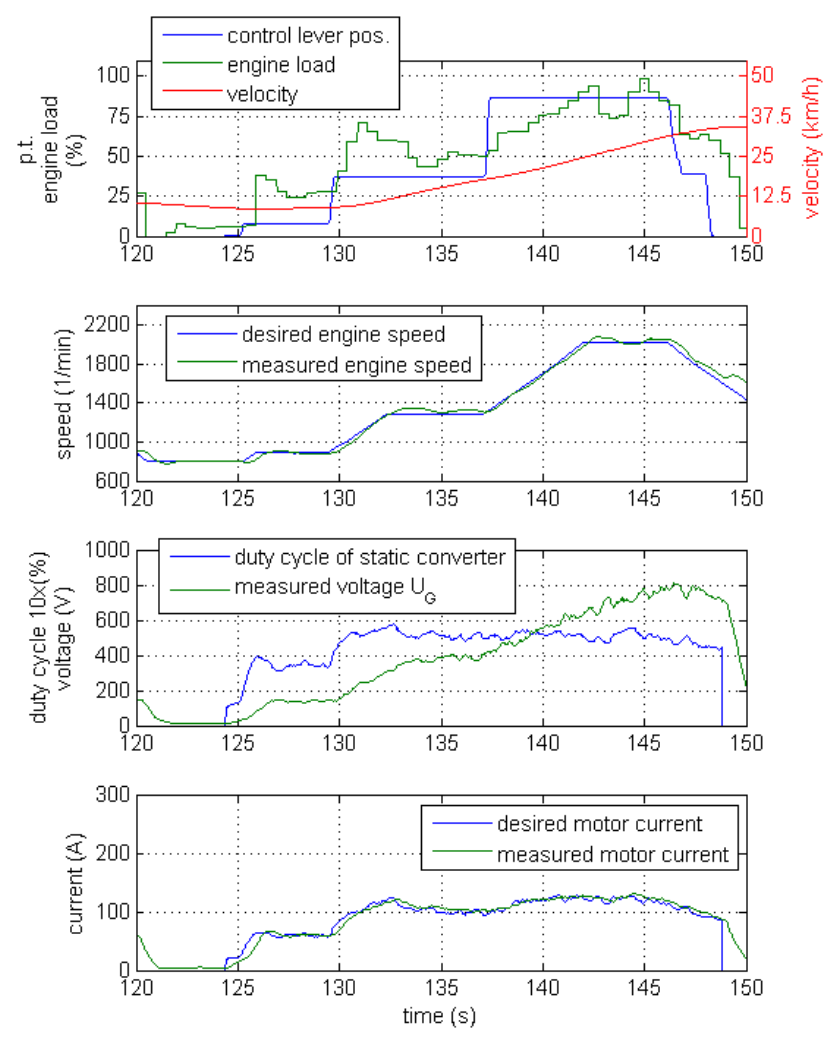

Fig. 8. Motor current control - changes in the desired p.t.
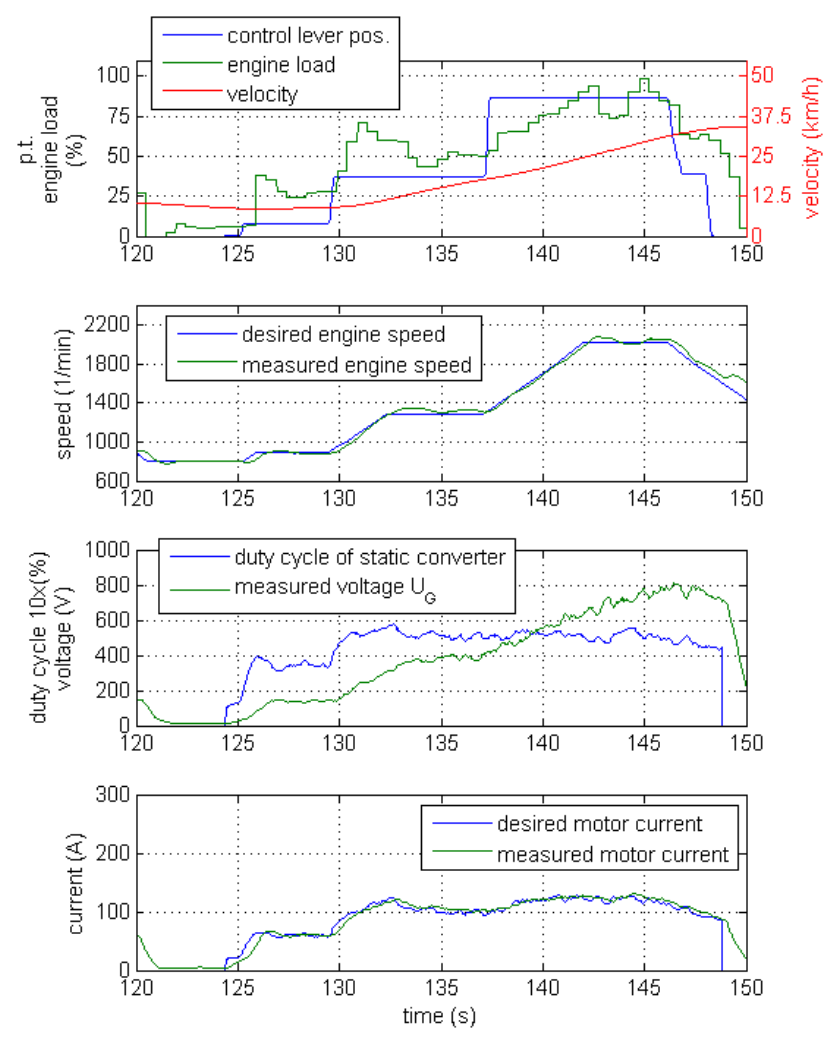

Fig. 9. Motor current control - acceleration at $100 \%$ p.t.

\section{Field weakening of DC traction motors}

Series wound DC motors are used. In order to achieve maximum speed, field weakening has to be used. There is only one level of field weakening used. It reduces the stator field to $55 \%$ of nominal value by switching the shunt resistor parallel to the excitation winding. One level is enough because of limited speed in metro $(40 \mathrm{~km} / \mathrm{h})$. The shunt resistor is switched with the contactor according to the measured voltage $U_{G}$ and vehicle velocity. At approx. $32 \mathrm{~km} / \mathrm{h}$ voltage at the rectifier output reaches the system limit $(900 \mathrm{~V})$ and the output power starts to drop. At that moment the shunt resistor is switched on. The vehicle can then reach $50 \mathrm{~km} / \mathrm{h}$. Transition back to full field is done when the generator is able to deliver an enough high voltage. Voltage hysteresis is used to prevent repeated transitions and a velocity threshold is used as a second condition in the algorithm to make the algorithm more robust.

The algorithm also checks the motor current in order to prevent the shunt contactor from damage. The excitation shunt contactor is designed to $100 \mathrm{~A}$. The control system limits the motor current to $180 \mathrm{~A}$ if the shunt contactor is on because the shunt contactor is designed to $100 \mathrm{~A}(55 \%$ of $180 \mathrm{~A}$ ). This check is only for safety reasons. No current limitation occurs if the generator load characteristic is well designed.

The detail of the field weakening is shown in Fig. 10. The motor current rises after the shunt was applied so that the tractive effort would be kept at the same level. Engine load and speed deviations are minimal during the transition. The transition is smooth without jerk.

The drive behaves similarly as in the model described in the paper [13].
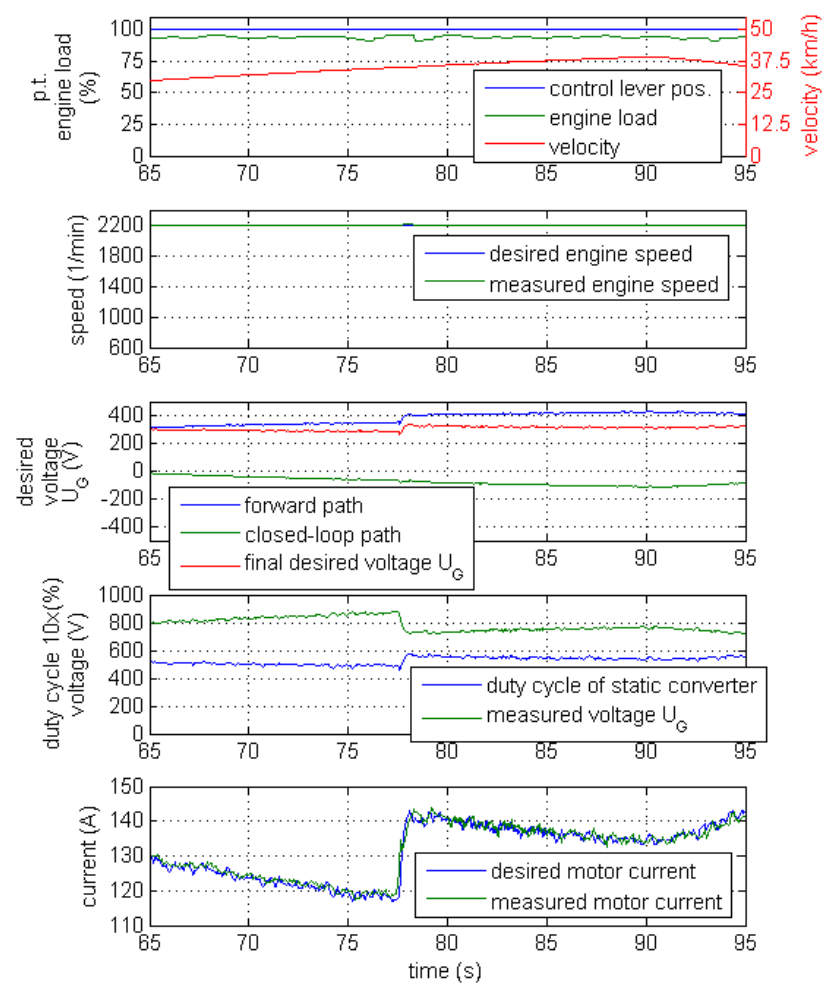

Fig. 10. Field weakening of traction motors. 


\section{CONCLUSION}

The traction drive structure and control of the motor truck WŽB 10.1-M for the Prague metro were briefly described. The proposed control structure is based on the structure successfully used on the previous manufactured vehicles (MUV, MMD, M27) equipped with hydrostatic transmission. New vehicle is equipped with the anti-slip protection as the new feature. The previous vehicles were not equipped with the anti-slip protection. Its function is satisfactory in the context of available time to development, available developers and cost. A new multifunction I/O module AX031201 from Axiomatic was used to acquire signals from sensors and to drive actuators. Due to high count programmable inputs/outputs, only this one I/O module was used. The same control computer RRCPU from AMiT as in the previous types of vehicles was used. Smaller space was then required in the electrical distributor board.

At this time (7/2017) only one vehicle is manufactured. The vehicle has been in duty since 6/2016. Auxiliary cooling fans for traction motor cooling will be added on the vehicle soon. The reasons were presented in the paper. After that another seven vehicles will be manufactured by CZ Loko company.

Hardware components of the control system and another software functions like velocity control and diagnostic functions were not described due to the limited extent of the text.

\section{ACKNOWLEDGMENT}

The paper was supported from the grant for Competence Centres Programme project No. TE520038.

\section{REFERENCES}

[1] MAŠEK, Zdeněk. Control System for Hydrostatic Transmission of Railcar M27. Transactions on Electrical Engineering. Vol. 3., 2014, p. 56-61. ISSN 1805-3386. Available from: http://www.transoneleng.org/2014/20143.pdf.

[2] MAŠEK, Zdeněk. Řízení trakčního pohonu vozidla MUV 74.2. In: Elektrotechnická zařízení $\mathrm{v}$ dopravě. Pardubice: Univerzita Pardubice, 2016.

[3] MAŠEK, Zdeněk, Jaroslav NOVÁK, Václav LENOCH a Ladislav MLYNAŘ́́K. Regulace hydrostatického přenosu trakčního výkonu speciálního kolejového vozidla MUV 74.1 N KSF: SEKEL 2013 mezinárodní konference učitelů elektrotechniky. Moravská Třebová: Univerzita Pardubice, 2013. ISBN 978-80-7395-625-7.

[4] MAŠEK, Zdeněk, Jaroslav NOVÁK a Václav LENOCH. Řízení trakčního hydrostatického pohonu na speciálním vozidle MUV 74 In: SETRAS 2012. Žilina: EDIS-vydavat'elstvo ŽU v Žilině, 2012, p. 91-100. ISBN 978-80-89276-39-4.

[5] PRIBYL, Bohuslav. Rozšírená kusová zkouška motoru TE023SKD001 6 SKD 860 043. SKD Trade, a.s., 2014.

[6] Uživatelská př́ručka systému řízení pohonu vozidla WŽB10.1-M. Verze 1.02. CZ LOKO a.s. 2016.

[7] Technické podmínky: Motorový univerzální vozík typu WŽB 10.1M. TP 8010-088. CZ Loko a.s. 2016.

[8] Schéma elektrické výzbroje vozidla WŽB 10.1-M. CZ Loko. 2016.

[9] BEDNÁRIK, Bernard, Milan POSPÍŠIL, Tomáš FECURA a Pavel LEHOCKÝ. Elektrické pohony dieselelektrických vozidel. Žilina: Žilinská univerzita v Žiline, 2003. ISBN 80-8070-038-9.

[10]DANZER, Jiří. Elektrická trakce III. V Plzni: Západočeská univerzita, 2003. ISBN 8070829451.

[11]LEONHARD, Werner. Control of electrical drives. 3rd ed. New York: Springer, c2001. ISBN 978-3-540-41820-7.

[12] HAPEMAN, Martin, James LONG a David PLETTE. Diesel Electric Locomotive Propulsion Systems-A Look into the Future. IEEE Transactions on Industry Applications. Volume: IA-22, Issue: 3. 1986. ISSN 0093-9994.

[13]BARNA, Grazyna. Simulation model of a series DC motor for traction rail vehicles. In: 2016 21st International Conference on Methods and Models in Automation and Robotics (MMAR). IEEE, 2016, s. 531-536. ISBN 978-1-5090-1866-6. https://doi.org/10.1109/MMAR.2016.7575192

[14] YAMASHITA, Michihiro a Tadashi SOEDA. Anti-slip re-adhesion control method for increasing the tractive force of locomotives through the early detection of wheel slip convergence. In: 2015 17th European Conference on Power Electronics and Applications (EPE'15 ECCE-Europe 2015). Geneva, Switzerland, 2015. ISBN 9789075815238. 